Original Research

\title{
Life Cycle Analysis of Rapeseed Oil Butyl Esters Produced from Waste and Pure Rapeseed Oil
}

\author{
Egle Sendzikiene*, Violeta Makareviciene, Irina Kazanceva
}

Laboratory of Chemical and Biochemical Research for Environmental Technology, Aleksandras Stulginskis University, Studentu 11, Akademija, LT-53361, Kaunas, Lithuania

Received: 11 May 2017

Accepted: 11 July 2017

\begin{abstract}
We compared the life cycle of rapeseed oil butyl esters (RBEs) made from waste rapeseed oil with that of RBEs made from conventional rapeseed oil. Chemical and biotechnological methods of production are considered. Sodium hydroxide was chosen as a catalyst for the chemical production method; for biotechnological production, the lipase lipozyme RM IM was chosen. The life cycle assessment, which was performed using the CML-IA baseline V 3.02/EU 25 method (SimaPro software), shows that using waste oil has a positive effect on all impact categories with the application of either biotechnological or chemical production methods. The use of RBEs from waste oil (using the biotechnological production method) led to a reduction of the following environmental impacts (compared with fossil fuel impacts): abiotic depletion up to $79.1 \%$, acidification $38.8 \%$, eutrophication $18.33 \%$, global warming $77 \%$, ozone layer depletion $90.12 \%$, human toxicity $71.8 \%$, fresh water aquatic ecotoxicity $9.01 \%$, marine water aquatic ecotoxicity $56.9 \%$, terrestrial ecotoxicity $0.191 \%$ (according to our results the impact of diesel on terrestrial ecotoxicity was small), and photochemical oxidation $36.8 \%$.
\end{abstract}

Keywords: life cycle, rapeseed oil butyl esters

\section{Introduction}

The impact of fuels on the environment is very important. This impact can be evaluated by measuring exhaust emissions and by performing a life cycle assessment. Fuels with a life cycle net energy ratio (NER) greater than 1, are classified as renewable biofuels [1-2]. NER is the ratio of the output energy to input energy that indicates the trend of energy productivity.
Life cycle assessment (LCA) is a method that allows for the evaluation of environmental impact (such as greenhouse gases, fossil fuel use, and ozone-depleting substances, etc.) caused by a product or process during its life cycle. LCA is analyzed in terms of a functional unit, which allows us to compare products with the same function. When comparing multiple products, commonly there are no products, which would be the best in all examined impact categories. So, the product with the smallest overall impact on the environment will be decided according to the value the assessor places on each individual category [3].

*e-mail: egle.sendzikiene@asu.lt 
From LCA it is possible to determine energy efficiency, thus enabling a comparison of total energy consumption of the production, preparation, treatment, and processing of raw materials into the final product (fuel). A greater level of fossil energy required for production is associated with a lower degree of renewability [2]. When zero or a small amount of mineral energy resources is used for the production of the fuel relative to the amount of energy derived from the final product, the fuel is considered fully renewable [4]. The net energy ratio is the ratio of the calorific value of the biodiesel fuel relative to the value of the energy demand of its production.

Janulis [1] determined that the value of the energy efficiency indicator depends on the country where the raw material grows, climatic conditions, yield, and biodiesel fuel production technology. Pleanjai and Gheewala [5] calculated the net energy ratios for palm oil methyl esters with and without by-products as 3.58 and 2.42, respectively. U.S. researchers established that the value of NER for canola oil methyl esters is 1.78 and that of soybean oil methyl esters is 2.05 [6]. The value of NER for fossil diesel fuel is 0.885 , while the average corresponding net energy ratio for rapeseed oil methyl esters (RMEs) is 1.9 .

Sales et al. [6] carried out net energy ratio analysis of subcritical ethylic biodiesel production from wet animal fat and vegetable oils. They determined that NER of their produced biodiesel is more than 2 [7].

The two leading software programs used for LCA studies are SimaPro (pre-sustainability 2012) and GaBi (PE-international 2012), both of which are commonly employed worldwide. In many cases the results are completely or very close to identical, but the observations presented in this paper nonetheless indicate differences both at the inventory level and in impact assessment. It appears that these differences come primarily from differences/errors in the different databases of SimaPro and GaBi. Hermann and Moltesen compared SimaPro and Gabi using the CML 2001 method. They noticed that the differences were modest except for marine aquatic as well as terrestrial ecotoxicity impact categories [8].

Raman et al. [9] performed an assessment of the life cycle of the production of biodiesel fuel (palm oil methyl esters) with the use of chemical and biochemical catalysts. The results show that, with the use of immobilized lipase, the negative impact of biodiesel fuel production on the environment decreases compared with the impact of production using traditional methods of synthesis owing to the repeated enzyme preparation. Raman et al. confirmed the results obtained by other researchers [9]. Farell and Cavangh [10] determined (using the IMPACT 2002+ method in SimaPro) that fossil diesel had the greatest impact in the categories of carcinogens, respiratory organics, and non-renewable energy. Biodiesels from new vegetable oil had the greatest impact in terms of respiratory inorganics, aquatic acidification, and eutrophication, as well as global warming, while waste vegetable oil had a slightly greater impact than did fossil diesel.

Varanda and colleagues conducted LCA of biodiesel from waste cooking oil using methanol and $\mathrm{H}_{2} \mathrm{SO}_{4}$ [11]. They determined that the use of waste cooking oil led to a reduced impact on all examined resources.

As for butyl ester production from waste cooking oil, LCAs have not yet been published. The purposes of this paper are to evaluate the life cycle and calculate the net energy ratio of RBEs produced using biological and chemical catalysts and compare the results with those of fossil fuel.

\section{Materials and Methods}

The life cycle indicators of the following cases were evaluated:

- Case 1. RBE production from rapeseed oil applying the biotechnological method.

- Case 2. RBE production from waste rapeseed oil applying the biotechnological method.

Table 1. Mass and energy values for each case used in the life cycle analysis of pure biodiesel fuel and fossil diesel production.

\begin{tabular}{|c|c|c|c|c|c|}
\hline & Case 1 & Case 2 & Case 3 & Case 4 & Case 5 \\
\hline Rapeseed oil & Crude & Waste & - & Crude & Waste \\
\hline Catalyst used & $\mathrm{NaOH}$ & $\mathrm{NaOH}$ & - & Lipase & Lipase \\
\hline Rapeseed (t) & 2.79 & - & - & 2.79 & - \\
\hline Rapeseed oil (kg) & 837 & - & - & 837 & - \\
\hline Waste rapeseed oil (kg) & - & 837 & - & - & 837 \\
\hline Butanol (kg) & \multicolumn{2}{|c|}{204.19} & - & \multicolumn{2}{|c|}{204.19} \\
\hline $\mathrm{NaOH}(\mathrm{kg})$ & 8.37 & 8.37 & - & - & - \\
\hline Phosphoric acid (kg) & \multicolumn{2}{|c|}{270} & - & - & - \\
\hline Electricity (MJ) & \multicolumn{2}{|c|}{1,459} & 5,000 & \multicolumn{2}{|c|}{1,313} \\
\hline Heat (MJ) & \multicolumn{2}{|c|}{1,445} & 27,300 & \multicolumn{2}{|c|}{1,173} \\
\hline
\end{tabular}


- Case 3. Fossil diesel production.

- Case 4. RBE production from rapeseed oil applying the chemical method.

- Case 5. RBE production from waste rapeseed oil applying the chemical method.

Mass and energy values for each case used in the LCA of pure biodiesel fuel and fossil diesel production are shown in Table 1.

Fuel is considered to be non-renewable if the amount of fossil fuel energy used in the production is significantly higher than the amount that is accumulated in the product, i.e., when the net energy ratio (NER) is less than 1 .

For evaluating NER all energy flows from production to disposal during the biodiesel fuel life cycle were calculated, including energy consumption in agriculture, oil extraction, and transesterification according to data presented in normative documents of the country. The life cycle energy ratio evaluation for rapeseed butyl esters produced from raw rapeseed oil involved a calculation of energy demands in rapeseed cultivation, oil extraction, and transesterification, while for rapeseed oil butyl esters produced from waste oil energy demands in agriculture were eliminated from calculations [12]. We also do not include the possibility of reusing the catalyst and butanol or the impact of lipase (that is why the amount of lipase used is not specified in Table 1), the process plant, or equipment construction. The data for diesel production (electricity and heat, MJ) are taken from "Energy Bandwidth for Petroleum Refining Processes," 2006 [13]. The net energy ratios were calculated for $1 \mathrm{t}$ of RBE according to the following equation:

$$
R_{1}=\frac{E_{B}}{E_{a c}+E_{g}}
$$

...where $E_{B}$ is calorific value of fuel $\left(\mathrm{MJ} / \mathrm{t}\right.$ of fuel), $\mathrm{E}_{\mathrm{ac}}$ is energy consumption for the cultivation of rapeseed and their preparation for oil extraction ( $\mathrm{MJ} / \mathrm{t}$ of biofuel), and $\mathrm{E}_{\mathrm{g}}$ is energy consumption for esterification and transesterification ( $\mathrm{MJ} / \mathrm{t}$ of biofuel). The calorific value of biofuel was determined by using an IKA C2000 basic calorimeter in accordance with the requirements of the standard DIN 51900.

Sima Pro (pre-sustainability 2012) software was applied for further LCA. As LCA is only a model of reality, some of the data for specific countries are not available, and simplifications of the processes are unavoidable. In the LCA, a CML 2 baseline 2000 method was chosen to compare all cases, allowing for a comparison of the results with those of other researchers. This method evaluates such characteristics:

- Depletion of abiotic resources is the impact category concerned with the protection of human welfare, human health, and ecosystem health. This impact category indicator is related to extraction of minerals and fossil fuels due to inputs into the system, which is why the impact of conventional diesel fuel is the greatest.
- Climate change is related to the emissions of greenhouse gases into the air. Factors are expressed as global warming potential for a time horizon of 100 years (GWP100) in $\mathrm{kg}$ carbon dioxide/kg emission.

- Human toxicity concerns the effects of toxic substances on the human environment. The health risks of exposure in the working environment are not included.

- Freshwater aquatic ecotoxicity refers to the impact on freshwater ecosystems of emissions of toxic substances into air, water, and soil.

- Marine ecotoxicity refers to the impact of toxic substances on marine ecosystems.

- Terrestrial ecotoxicity refers to the impact of toxic substances on terrestrial ecosystems.

- Photo-oxidant formation is the formation of reactive substances (mainly ozone) that are injurious to human health and ecosystems, and that may damage crops.

- Acidification causes a wide range of impact on soil, groundwater, surface water, organisms, ecosystems, and materials (buildings).

- Eutrophication includes all impact that result from excessive levels of macro-nutrients in the environment produced by emissions of nutrients into the air, water, and soil.

\section{Results and Discussion}

\section{Biodiesel NER Calculation and Comparison with Fossil Diesel}

As waste rapeseed oil was used in RBE synthesis, the energy consumption involved in agriculture (seed sowing, fertilizing, agricultural labour, and squeezing the seeds) was not included in the calculation of the net energy ratio and LCA. To produce $1 \mathrm{t}$ of RBE, $0.837 \mathrm{t}$ of waste rapeseed oil was necessary. Energy consumption for transportation of $1 \mathrm{t}$ of waste oil by lorry (with capacity $7.5 \mathrm{t}$ ) to the biodiesel production plant, when the distance was $100 \mathrm{~km}$, was $80.35 \mathrm{MJ}$.

The energy consumption for transesterification with butanol was calculated in accordance with the established optimal process conditions and on the basis of the data presented in the technical documentation of JSC Vaizga. It was assumed that RBE would be produced chemically using the same equipment and, after minor modifications and additions, the same equipment would also be used for the production of RBE by applying the biotechnological method. Considering that butanol, in contrast to synthetic methanol, is obtained by biotechnological methods, its energy contribution was calculated according to the value of the life cycle energy efficiency indicator of butanol, 1.88 , and the calorific value of butanol [14].

The data presented in Table 2 show that the primary energy accumulated in chemical materials is greater in RBE production when the biocatalyst lipase is used. The energy demand for chemical materials in this case equals 5,741.37 MJ/t. When the chemical method is 
Table 2. Energy consumption for oil transesterification.

\begin{tabular}{|c|c|c|}
\hline Classification & $\begin{array}{c}\text { Energy input, } \\
\mathrm{MJ} / \mathrm{t} \mathrm{RBE} \\
\text { (biotechnological } \\
\text { method) }\end{array}$ & $\begin{array}{c}\text { Energy input, } \\
\mathrm{MJ} / \mathrm{t} \mathrm{RBE} \\
\text { (chemical } \\
\text { method) }\end{array}$ \\
\hline \multicolumn{3}{|c|}{ Oil transesterification } \\
\hline Electric power & $1,313.1$ & 1,459 \\
\hline Heat power & $1,173.07$ & $1,445.42$ \\
\hline $\begin{array}{l}\text { Primary accumulated } \\
\text { energy in equipment }\end{array}$ & $1,988.58$ & $1,807.8$ \\
\hline Total & $4,474.75$ & $4,712.22$ \\
\hline \multicolumn{3}{|c|}{ Accumulated energy in chemicals } \\
\hline Butanol & $3,732.57$ & $3,732.57$ \\
\hline Catalyst & $2,008.80$ & 251.10 \\
\hline Phosphoric acid & 0.00 & 180.10 \\
\hline Total & $5,741.37$ & $4,163.77$ \\
\hline Total & $10,216.12$ & $8,875.99$ \\
\hline
\end{tabular}

used, the value is $4,163.77 \mathrm{MJ} / \mathrm{t}$, attributable to greater energy accumulating in the bio-catalyst. Compared with biotechnological butyl ester production, $18.84 \%$ more thermal energy and 10\% more electrical energy is consumed in the transesterification of rapeseed oil by the chemical method because of the higher transesterification process temperature $\left(105^{\circ} \mathrm{C}\right)$ used in the production of RBE with a chemical catalyst. Total energy consumption for the production of biodiesel using the biotechnological method is $10,216.12 \mathrm{MJ} / \mathrm{t} \mathrm{RBE}$, and the value for production using the chemical method is $8,875.99 \mathrm{MJ} / \mathrm{t}$ RBE.

The calculated life cycle net energy ratio for RBE produced by applying the biotechnological method is lower than that of RBE produced by the chemical method (Table 3). The values of by-products were not included in the calculations.

The results show that the net energy ratio of waste oil butyl esters is higher than that of butyl esters produced from crude rapeseed oil. As mentioned above, the net energy ratios of the following esters were determined: palm oil methyl esters at 2.42 [5] and canola and soybean oil methyl esters at 1.78 and 2.05, respectively [6]. Mohammadshirazi and colleagues performed an energy analysis of biodiesel production from waste cooking oil and determined that the energy ratio was 1.49 [15]. The difference from our results could be explained by the use of different alcohols transesterification values and thus the different synthetic conditions. Other researchers from Piedmont Biofuels [16] calculated the net energy ratio for biodiesel from waste vegetable oil, including waste materials, and from chicken farm fat as 7.85 and 3.00, respectively. Shonnard and Williams [17] investigated the NER of biodiesel from camelina oil and calculated that the NER was approximately 4.00. Cho and colleagues [18] determined that the NER of biodiesel from palm fatty acid distillate was 3.23. Altamirano et al. determined that the NER for soybean oil ethyl and methyl esters were, respectively, 2.85 and 3.55 [19].

\section{Biodiesel LCA \\ (by CML 2 Baseline 2000 Method)}

The results of LCA using the CML 2 baseline 2000 method are introduced in Table 4, and the comparative analysis (in which the largest value was assigned a value of $100 \%$ ) is shown in Fig. 1.

According to the LCA using the CML-2 2000 baseline method, conventional diesel has the largest negative influence on the environment in the following categories: abiotic depletion, global warming, ozone layer depletion, human toxicity, and photochemical oxidation $(100 \%)$. Using waste rapeseed oil in biodiesel production reduces the environmental impact in all categories except photochemical oxidation. In this case, biodiesel production from the crude rapeseed oil accounts for the lower impact. As for the biodiesel production method, it is clear that the biotechnological method has a lower influence in all categories.

\section{Depletion of Abiotic Resources}

The data in Fig. 1-2 and Table 4 show that the impact on abiotic depletion of chemical biodiesel fuel production from pure rapeseed oil is greater than that of biodiesel fuel production from waste oil (respectively, 32.2 and 24.7\%) compared with fossil diesel fuel production (100\%).

Their results and a comparison with our studies are shown in Table 5 and Fig. 2.

In the case of the application of the biotechnological method for biodiesel fuel production from pure rapeseed oil, the impact on abiotic depletion is $27.5 \%$, and in the case of the application of the same methodology to waste oil, the impact is $20.9 \%$. The result is comparable with the results obtained by other researchers [8], who determined $15.4 \mathrm{~kg} \mathrm{Sb}$ eq for RMEs and 13.4 for rapeseed ethyl esters

Table 3. Energy inputs for biodiesel production and the net energy ratio of RBE from waste and crude rapeseed oil.

\begin{tabular}{|c|c|c|c|c|}
\hline \multirow[b]{2}{*}{ Rapeseed oil } & \multicolumn{2}{|c|}{ Biotechnological method } & \multicolumn{2}{|c|}{ Chemical method } \\
\hline & Crude & Waste & Crude & Waste \\
\hline Total energy input for biodiesel production, $\mathrm{MJ} / \mathrm{t} \mathrm{RBE}$ & $31,976.4$ & $10,296.47$ & $30,636.27$ & $8,956.34$ \\
\hline Net energy ratio (NER) & 1.19 & 3.69 & 1.24 & 4.24 \\
\hline
\end{tabular}


Table 4. Impact categories of RBE, applying CML2 baseline 2000 method.

\begin{tabular}{|c|c|c|c|c|c|c|}
\hline Impact category & Unit & Case 1 & Case 2 & Case 3 & Case 4 & Case 5 \\
\hline Abiotic depletion & $\mathrm{kg} \mathrm{Sb}$ eq & 14.5 & 11 & 52.9 & 17 & 13.1 \\
\hline Acidification & $\mathrm{kg} \mathrm{SO}_{2}$ eq & 29.1 & 5.24 & 19 & 35.5 & 11.4 \\
\hline Eutrophication & $\mathrm{kg} \mathrm{PO}_{4}^{-3} \mathrm{eq}$ & 15.3 & 1.51 & 4.81 & 18 & 4.14 \\
\hline Global warming (GWP100) & $\mathrm{kg} \mathrm{CO}_{2}$ eq & 1,660 & 997 & 4,330 & 2,050 & 1,330 \\
\hline Ozone layer depletion (ODP) & $\mathrm{kg}$ trichlorofluoromethane eq & 0.000326 & 0.0000975 & 0.000986 & 0.000364 & 0.00013 \\
\hline Human toxicity & kg 1.4-dichlorbenzene eq & 511 & 362 & 1,280 & 1,220 & 1,050 \\
\hline $\begin{array}{c}\text { Fresh water aquatic } \\
\text { ecotoxicity }\end{array}$ & $\mathrm{kg}$ 1.4-dichlorbenzene eq & 3,850 & 229 & 651 & 4,680 & 1,040 \\
\hline Marine aquatic ecotoxicity & kg 1.4-dichlorbenzene eq & 994,000 & 486,000 & $1,600,000$ & $1,950,000$ & $1,410,000$ \\
\hline Terrestrial ecotoxicity & kg 1.4-dichlorbenzene eq & 1,570 & 1.68 & 4.69 & 1580 & 4.67 \\
\hline Photochemical oxidation & $\mathrm{kg} \mathrm{C}_{2} \mathrm{H}_{4}$ eq & 0.275 & 0.572 & 0.904 & 0.552 & 0.836 \\
\hline
\end{tabular}

(REEs). We obtained the following results: 14.5 and 17 for RBEs from crude oil, 11 and 13.1 RBEs from waste (using chemical and biotechnological methods, respectively), and $52.9 \mathrm{~kg} \mathrm{Sb}$ eq. for fossil fuel. The differences could be due to the applications of different alcohols in the transesterification processes and different synthetic conditions.

\section{Climate Change}

Our data show that the most negative impact on global warming was due to fossil fuel $(100 \%)$. On the other

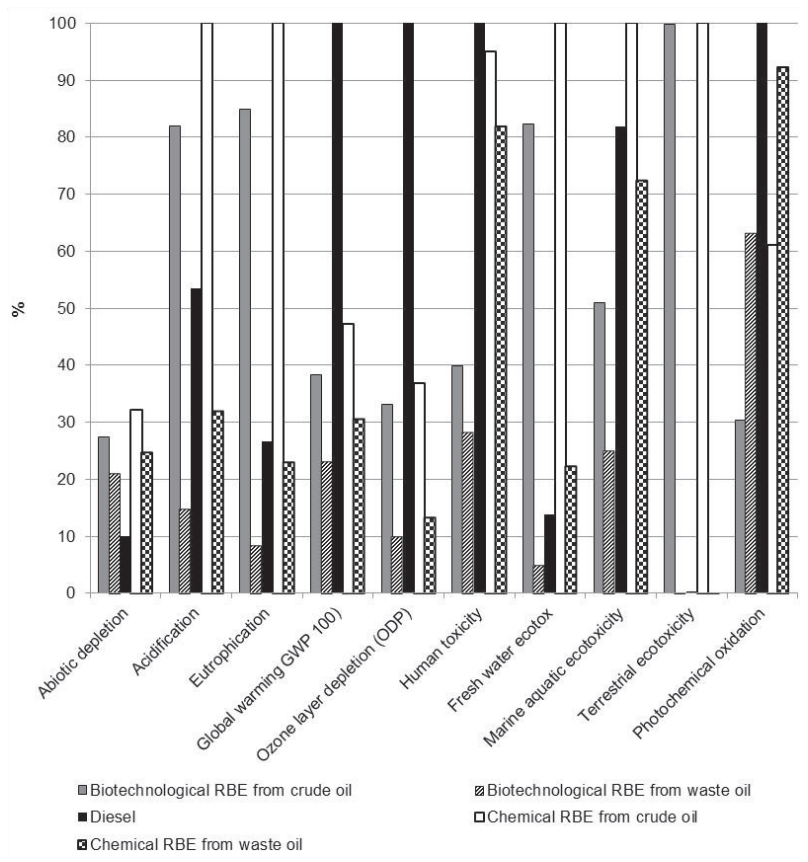

Fig. 1. Comparison of impact of butylester, depending on production method and raw material, evaluated by applying the CML-2 baseline 2000 method (100\% was assigned for the biggest value, which characterized fuel impact on the environment). hand, the negative impact on global warming of biodiesel fuel production from pure rapeseed oil by applying the chemical method is greater than the impact of biodiesel fuel production by the same manner from waste oil (47.3 and $30.6 \%$, respectively, compared with the value of fossil fuel). When the biotechnological production method is applied, the impact on global warming when pure rapeseed oil is used for biodiesel fuel production is slightly lower and equals $38.3 \%$, and in the case of waste oil use, this value reaches $23 \%$. RBEs from waste oil emitted $997 \mathrm{~kg} \mathrm{CO}$ eq when the chemical method was applied and 1,330 when the biotechnological method was applied. For crude oil, the results were 1,660 and 2,050 kg $\mathrm{CO}_{2}$ eq (for the chemical and biotechnological methods, respectively); fossil diesel fuel emitted $4,330 \mathrm{~kg} \mathrm{CO}$ eq. Spirinckx and Ceuterick [20] noted that the greenhouse effect was reduced by $50 \%$ using biodiesel compared with fossil diesel.

\section{Stratospheric Ozone Depletion}

When biodiesel fuel is produced from pure rapeseed oil by applying biotechnological and chemical methods, the impact on the ozone layer depletion is, respectively, $33.1 \%$ (or $0.000364 \mathrm{~kg}$ of trichlorofluoromethane eq) and $36.9 \% \quad(0.000326 \mathrm{~kg}$ of trichlorofluoromethane eq) compared with the impact of fossil fuel $(100 \%$; $0.000986 \mathrm{~kg}$ of trichlorofluoromethane eq). In the case of biodiesel fuel production from waste oil applying biotechnological and chemical methods, the impact on the ozone layer depletion is, respectively, $9.88 \%$ $(0.00013 \mathrm{~kg}$ of trichlorofluoromethane eq) and $13.2 \%$ $(0.000326 \mathrm{~kg}$ of trichlorofluoromethane eq). The impacts on the ozone layer depletion of the production of RBEs from crude oil by applying both of the methods are very similar and are more than the impacts of producing RBEs from waste oil. 


\section{Human Toxicity}

The impact on human toxicity of biodiesel fuel production from pure rapeseed oil is $39.8 \%$ or $511 \mathrm{~kg}$ of 1.4-dichlorobenzene eq (for the biotechnological method), and $95 \%$ or $1,220 \mathrm{~kg}$ of 1.4-dichlorobenzene eq (for the chemical production method), compared with diesel fuel $(100 \%, 1,280 \mathrm{~kg}$ of 1,4 -dichlorobenzene eq). In the case of waste oil use, the above-mentioned impact values equal $28.2 \%$ (362 kg of 1,4-dichlorobenzene) and 82\% (1,220 kg of 1,4-dichlorobenzene eq), respectively.

\section{Freshwater Aquatic Ecotoxicity}

The impact of biodiesel fuel production on freshwater aquatic ecotoxicity depends on the production method and the raw material. When pure oil is used as the raw material, fresh water aquatic ecotoxicity equals $82.3 \%(3,850 \mathrm{~kg}$ 1,4-dichlorobenzene eq) in the case when the biotechnological method is applied; when the chemical method is applied, the freshwater aquatic ecotoxicity is $100 \% \quad(4,680 \mathrm{~kg}$ 1,4-dichlorobenzene eq). For waste oil transesterification, the data are $4.89 \%$ (229 kg 1,4-dichlorobenzene eq) and 22.3\% (1,040 kg 1,4-dichlorobenzene eq) when applying the biotechnological and chemical methods, respectively. The results show that the production of biodiesel from pure oil, when applying the biotechnological method, has a more negative influence than other fuels. The impact of diesel fuel on freshwater aquatic ecotoxicity is $13.9 \%$ (651 $\mathrm{kg}$ of 1,4-dichlorobenzene eq).

\section{Marine Ecotoxicity}

The impact on marine aquatic ecotoxicity from applying the biotechnological method to butyl ester production from pure rapeseed oil is $51 \%(994,000 \mathrm{~kg}$ of 1,4-dichlorobenzene eq); the impact from waste oil is $25 \%(486,000 \mathrm{~kg}$ 1,4-dichlorobenzene eq). When the chemical method is applied, the impacts are $72.4 \%$ $(1,410,000 \mathrm{~kg}$ 1,4-dichlorobenzene eq) and $100 \%$ $(1,950,000 \mathrm{~kg}$ 1,4-dichlorobenzene eq) from waste and pure rapeseed oil, respectively. For diesel fuel production, the impact is $81.9 \%(1,600,000 \mathrm{~kg} 1,4$-dichlorobenzene eq).

\section{Terrestrial Ecotoxicity}

The impacts on terrestrial ecotoxicity of the production of RBEs from crude oil are 99.8\% $(1,570 \mathrm{~kg}$ 1,4-dichlorobenzene eq) and $100 \%$ $(1,580 \mathrm{~kg}$ 1,4-dichlorobenzene eq) for the biotechnological and chemical methods, respectively. The impacts of the production of RBEs from waste oil are $0.106 \%$ (1.68 kg 1,4-dichlorobenzene eq) and $0.296 \%$ (4.67 kg 1,4-dichlorobenzene eq), applying the biotechnological and chemical methods, respectively, and the impact of diesel fuel production as $0.297 \%$ (4.69 kg 1,4-dichlorobenzene eq).

\section{Photo-Oxidant Formation}

In this case, the impact on photochemical oxidation when the chemical method is applied for biodiesel fuel production is larger compared with the impact when the biotechnological production method is applied: $61.1 \%\left(0.552 \mathrm{~kg} \mathrm{C}_{2} \mathrm{H}_{4}\right.$ eq) and $30.4 \%\left(0.275 \mathrm{~kg} \mathrm{C}_{2} \mathrm{H}_{4}\right.$ eq), respectively, from pure rapeseed oil; $92.4 \%(0.836 \mathrm{~kg}$ $\mathrm{C}_{2} \mathrm{H}_{4}$ eq $)$ and $63.2 \%\left(0.572 \mathrm{~kg} \mathrm{C}_{2} \mathrm{H}_{4}\right.$ eq $)$, respectively, from waste oil. The largest impact was shown by diesel fuel $\left(100 \%, 0.904 \mathrm{~kg} \mathrm{C}_{2} \mathrm{H}_{4}\right.$ eq).

\section{Acidification}

The impacts are $68 \%$ and $67.3 \%$ for biotechnological and chemical production methods, respectively. The biggest impact of acidification is derived from $\mathrm{RBE}$ production from pure oil applying the chemical method $\left(100 \% ; 11.4 \mathrm{~kg} \mathrm{SO}_{2}\right.$ eq), followed by the values from crude oil using a biocatalyst $\left(82 \% ; 29.1 \mathrm{~kg} \mathrm{SO}_{2}\right.$ eq), from waste oil applying the chemical production method $(32 \% ; 11.4 \mathrm{~kg}$ $\mathrm{SO}_{2}$ eq), and from waste oil applying the biotechnological method (14.7\%; $5.24 \mathrm{~kg} \mathrm{SO} 2 \mathrm{eq})$; the impact of diesel fuel is $53.5 \%$ (19 $\mathrm{kg} \mathrm{SO}$ eq). The tendency of increased acidification due to the production of biodiesel from crude rapeseed oil was described by Spirinckx [20]; according to their data, acidification caused by biodiesel increased by more than $10 \%$.

\section{Eutrophication}

The differences in the impacts are $76.53 \%$ and $77 \%$ for the biotechnological and chemical production methods, respectively. The biggest impact of eutrophication is due

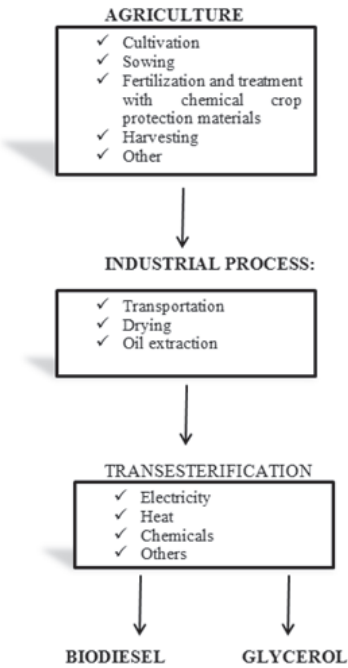

Case 1, 4

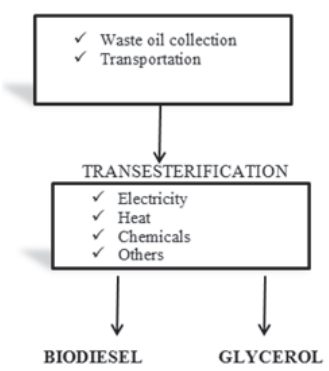

Case 2, 5
Fig. 2. System boundaries for LCA from rapeseed oil: Cases 1 and 3 (crude oil, lipase, and $\mathrm{NaOH}$, respectively) and Cases 2 and 5 (waste oil, lipase, and $\mathrm{NaOH}$, respectively). 
to $\mathrm{RBE}$ production from pure oil applying the chemical method (100\%; $18 \mathrm{~kg} \mathrm{PO}$ eq), followed by values from crude oil using a biocatalyst $(84.9 \% ; 15.3 \mathrm{~kg} \mathrm{PO}$ eq), from waste oil using the chemical production method $\left(23 \% ; 4.14 \mathrm{~kg} \mathrm{PO}_{4}\right.$ eq), and from waste oil using the biotechnological method $\left(8.37 \% ; 1.51 \mathrm{~kg} \mathrm{PO}_{4}\right.$ eq); the value for diesel fuel is $26.7 \%\left(4.81 \mathrm{~kg} \mathrm{PO}_{4}\right.$ eq). Other researchers [20] have observed that eutrophication from biodiesel production was more than $80 \%$ higher than that of fossil diesel.

Summarizing the results, it is clear that when both methods are compared that the use of the biocatalyst tends to reduce all impacts. Applying the biotechnological method, the following reductions were observed relative to the chemical method for RBE production from crude oil and waste oil, respectively: abiotic depletion of 4.7 and $3.8 \%$, acidification of 18 and $17.3 \%$, eutrophication of 15.1 and $14.63 \%$, global warming of 9 and $7.6 \%$, ozone layer depletion of 3.8 and $3.32 \%$, human toxicity of 55.2 and $53.8 \%$, freshwater aquatic ecotoxicity of 17.7 and $17.41 \%$, marine water ecotoxicity of 49 and $47.4 \%$, terrestrial ecotoxicity of 0.2 and $0.19 \%$, and photochemical oxidation of 30.7 and $29.2 \%$. Harding and colleagues [21] compared the life cycles using inorganic and biological catalysis for the production of biodiesel (RMEs). They noticed that the use of the biological catalyst in biodiesel production led to a reduction of all impacts. According to their results, some impacts were similar to our data, while other impacts differed: abiotic depletion was reduced by $4 \%$; acidification by $4 \%$; eutrophication, in contrast to our data, was without change; global warming by $3 \%$; ozone layer depletion by $6 \%$; human toxicity by $8 \%$; freshwater aquatic ecotoxicity by $12 \%$; marine water ecotoxicity by $9 \%$; terrestrial ecotoxicity by $37 \%$; and photochemical oxidation by $2 \%$.

As mentioned above, RBE production from waste oil had more advantages than production from crude oil; only the impact on photochemical oxidation was higher (approximately 30\%) than that of producing RBEs from pure oil. Based on these results, we could propose that the production of RBEs from waste oil applying the biotechnological method was the most harmless among all the investigated fuels. The use of such fuel led to a reduction of the following impacts (compared with those of fossil fuel): abiotic depletion up to $79.1 \%$, acidification $38.8 \%$, eutrophication $18.33 \%$, global warming $77 \%$, ozone layer depletion $90.12 \%$, human toxicity $71.8 \%$, freshwater aquatic ecotoxicity $9.01 \%$, marine water aquatic ecotoxicity $56.9 \%$, terrestrial ecotoxicity $0.191 \%$ (according to our results, the impact of diesel on terrestrial ecotoxicity was small), and photochemical oxidation $36.8 \%$

In comparison with other researchers' results, it is necessary to note that the exact data and the relative data (in percent) could differ due to the use of different alcohols, transesterification conditions, and LCA methods.

Our results regarding the production of RBEs from waste oil using biological catalysts corresponded to the results of Varanda [11], who applied the IMPACT 2000+

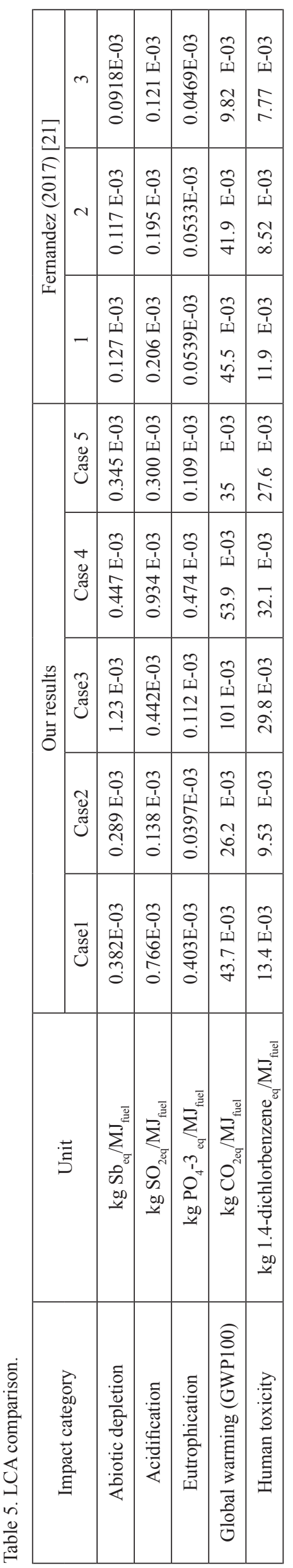


method for the LCA of biodiesel production from palm and used oil, determining that biodiesel production from used oil showed a lower environmental impact compared with biodiesel production from pure palm oil.

A similar tendency comparing fossil fuel and biodiesel was observed in the research of Farell [10]. Although they applied another method to assess the life cycle (IMPACT 2002+), their results showed that fossil diesel showed a lower impact on acidification. The greatest impact on acidification was caused by biodiesel production from crude oil (which we also determined for biodiesel production when the chemical production method was applied). Biodiesel production from waste oil showed an $80 \%$ lower impact than that from crude oil and an $8 \%$ higher impact than that from fossil diesel. As for eutrophication, biodiesel production from waste oil had a $50 \%$ lower impact than that of biodiesel production from new vegetable oil and more than a $45 \%$ higher impact than that of fossil diesel production.

Peñarrubia Fernandez et al. [22] investigated the life cycle of biodiesel (methylesters) from virgin and waste soybean oil, applying both catalysts ( $\mathrm{NaOH}$ and lipase) under Brazilian conditions. They examined the life cycle of biodiesel produced from soybean oil and applying $\mathrm{NaOH}(1)$, soybean oil + lipase (2), and waste oil +lipase (3). Their results and a comparison with our studies are shown in Table 5. Our results were categorized per MJ fuel for comparison. Comparing our results, it is obvious that diesel is characterized as the worst in such impact categories as abiotic depletion and global warming. In other categories diesel could be smaller than biodiesel due to its higher caloric value compared with biodiesel. Speaking about biodiesel, the tendencies are the same: the biotechnological biodiesel production method led to a decrease of all the impact categories as shown in Table 5 compared with the conventional method. Though the differences between results are not very high, they could be explained by the different alcohol and vegetable oil used, as well as the fact that the experiments took place in different countries.

\section{Conclusions}

The calculation of the NER (more than 1) shows that butyl esters produced from waste oil applying biotechnological and chemical methods could be defined as renewable biofuel. The net energy ratio of $\mathrm{RBE}$ production from waste oil is 3.69 when the biotechnological method is applied and 4.24 when using the chemical method. As for RBE production from crude oil, the results are 1.19 and 1.24 for the biotechnological and chemical methods, respectively. LCA using the CML-IA baseline V 3.02/EU 25 method (SimaPro software) shows that using waste oil has a positive effect on all impact categories when applying either the biotechnological or the chemical production methods. The use of RBEs from waste oil (biotechnological production method) led to a reduction of the following impacts (compared with fossil fuel): abiotic depletion up to $79.1 \%$, acidification $38.8 \%$, eutrophication $18.33 \%$, global warming $77 \%$, ozone layer depletion $90.12 \%$, human toxicity $71.8 \%$, freshwater aquatic ecotoxicity $9.01 \%$, marine water aquatic ecotoxicity $56.9 \%$, terrestrial ecotoxicity $0.191 \%$ (according to our results, the impact of diesel for terrestrial ecotoxicity was small), and photochemical oxidation $36.8 \%$.

\section{Acknowledgements}

The Authors wish to thank the Pre Consultant Company for providing the software for the study presented in this paper.

\section{References}

1. JANULIS P. Reduction of energy consumption in biodiesel fuel life cycle. Renew. Energ. 29, 2004.

2. PRADHAN A., SHRESTHA D.S., MCALOON A., YEE W., HAAS M., DUFFIELD SHAPOURI J.A. Energy Life-Cycle Assessment of Soybean Biodiesel. Agricultural Economic Report Number. 2009.

3. STOW M., MCMANUS M.C., BANNISTER C. A life cycle assessment comparison of rapeseed biodiesel and conventional diesel. Sustainable Vehicle Technologies. 2012.

4. USDA, Energy Life-Cycle Assessment of Soybean Biodiesel, 2009. http://www.usda.gov/oce/reports/energy/ ELCAofSoybeanBiodiese191409.pdf

5. PLEANJAI S., GHEEWALA S.H. Full chain energy analysis of biodiesel production from palm oil in Thailand. Appl. energ. 86 (1), 2009.

6. SALES E.A., GHIRARDI M.L., JORQUERA O. Subcritical ethylic biodiesel production from wet animal fat and vegetable oils: A net energy ratio analysis. Energ. Convers. Manage. 2016. http://dx.doi.org/10.1016/j. enconman.2016.08.015

7. FORE S.R., PORTER P., LAZARUS W. Net energy balance of small-scale on-farm biodiesel production from canola and soybean. Biomass Bioenerg. 35 (5), 2011.

8. HERRMANN, I.T., MOLTESEN, A. Does it matter which Life Cycle Assessment (LCA) tool you choose? a comparative assessment of SimaPro and $\mathrm{GaBi}$, Journal of Cleaner Production, 2014, http://dx.doi.org/10.1016/j. jclepro.2014.08.004

9. RAMAN J.K., TING V.F.W., POGAKU R. Life cycle assessment of biodiesel production using alkali, soluble and immobilized enzime catalyst processes. Biomass. Bioenerg. 35 (10), 2011.

10. FARELL S., CAVANGH E. An introduction to life cycle assessment with hands-on ecperiments for biodiesel production and use. Education for chemical engineers. 9, 2014.

11. VARANDA M.G., PINTO G., MARTINS F. Life cycle analysis of biodiesel production. Fuel Process Technol 92, 2011.

12. KAZANCEVA I, SENDZIKIENE E. Life cycle energy efficiency indicators of rapeseed oil butyl esters. Rural development. 2013.

13. Energy Bandwidth for Petroleum Refining Processes. United States. Department of Energy. Office of Energy 
Efficiency and Renewable Energy, 2006, available at https:// books.google.lt/books/about/Energy_Bandwidth_for_ Petroleum_Refining.html?id=cOswngAACAAJ\&redir_ esc $=y$.

14. VAN DER MERWE A.B., CHENG H., GÖRGENS J.F., KNOETZE J.H. Comparison of energy efficiency and economics of process designs for biobutanol production from sugarcane molasses. Fuel. 105, 2013.

15. MOHAMMADSHIRAZI A., AKRAM A., RAFIEE S., KALHOR E.B. Energy and cost analyses of biodiesel production from waste cooking oil. Renew Sust Energ Rev. 33, 2014

16. Piedmont Biofuels Final LCA Report, 2012, available at http://www.biofuels.coop/wp-content/uploads/2012/05/ LCA2011.pdf

17. SHONNARD D., WILLIAMS L.Camelina-derived jet fuel and diesel: sustainable advanced biofuels. Environ Prog Sustain. 29, (3), 2010.

18. CHO H.J., KIM J.K., AHMEND F., YEO Y.K. Lifecycle greenhouse gas emissions and energy balances of a biodiesel production from palm fatty acid distillate (PFAD). Appl Energ. 111, 2013.
19. ALEJOS ALTAMIRANO C.A., YOKOYAMA L., DE MEDEIROS J.L., DE QUEIROZ FERNANDES ARAUJO. Ethylic or methylic route to soybean biodiesel? Tracking environmental answers through life cycle assessment. Appl Energy, 2016, http://dx.doi.org/10.1016/j. apenergy.2016.05.017

20. SPIRINCKX C., CEUTERICK D. Biodiesel and Fossil diesel fuel: comparative life cycle assessment. 6th SETACEurope meeting: LCA - selected papers, Int.J.LCA 1 (3), 1996.

21. HARDING K.G., DENNIS J.S., VON BLOTTNITZ H., HARRISON S.T.L. A life-cycle comparison between inorganic and biological catalysis for the production of biodiesel. J Clean Production. 16, 2007.

22. PEÑARRUBIA FERNANDEZ I.A., LIUA D-H., ZHAO J. LCA studies comparing alkaline and immobilized enzyme catalyst processes for biodiesel production under Brazilian conditions. Resources, Conservation and Recycling. 119, 2017. 